7. Reprod. Fert. (1971) 27, 455-458

\title{
CHANGES IN SOME BLOOD INDICES DURING COPULATION IN THE BOAR
}

\author{
Z. EWY, T. KOLGZAK, S. WIERZBOWSKI AND E. WIERZCHOŚ \\ Department of Animal Physiology and Department of Animal Reproduction and A.I., \\ Institute of Zootechnics, Balice, Kraków, Poland
}

(Received 7th April 1971)

Klumbies \& Kleinsorge (1950) and Fox \& Fox (1969) recorded blood pressure, heart rate and respiratory changes during ejaculation elicited by masturbation and natural coitus. Jakubowski (1966) reported that a rise in the heart rate occurred and Wierzchos (1970) observed a rise in blood pressure, heart rate and respiratory rate during copulation in the boar. According to Wójcik (1969), the blood in copulating rams contains substances which induce incomplete contractions of the isolated vas deferens. Gudat \& Schnell (1970) found that the levels of erythrocytes, leucocytes, haemoglobin, plasma glucose and transaminases, GOT and GPT, were higher in boars immediately after copulation than before it. Changes in the blood constituents of the male during copulation do not, however, appear to have been described until now. Since copulation in the boar is a relatively prolonged process, it affords favourable conditions for studying such changes.

Observations were carried out on four Polish Large White boars of 150 to $200 \mathrm{~kg}$ body weight. Semen was collected by manual technique using a dummy sow. The time and course of the successive fractions of ejaculate were noted. Ejaculates followed by control blood samples were collected for 4 consecutive days from each boar. Blood samples (2 to $3 \mathrm{ml}$ ) obtained from the coccygeal artery after tail-lopping were collected into tubes containing heparin or ammonium oxalate. According to Spincer, Rook \& Towers (1969), in sows the levels of constituents in the arterial blood and in the blood collected from the tail are similar. Four to six blood samples were collected in the stall and then the boar was introduced to the dummy. Blood was collected continuously throughout the period of sexual excitement and copulation and for 5 to $7 \mathrm{~min}$ after ejaculation. Further samples were collected thereafter every 2 to $4 \mathrm{~min}$. The total blood loss during each copulation did not exceed $100 \mathrm{ml}$. For control estimations, blood was collected in the stall for a period similar to that of the semen collection.

The heparinized blood was used for filling the haematocrit capillary and for preparing the basic dilution to determine the leucocyte count. Plasma glucose was estimated with glucose oxidase and peroxidase (Bergmeyer \& Bernt, 1962), and the concentration of lactic acid in the blood samples was measured by the method of Barker \& Summerson (1941). Blood and plasma sodium and blood potassium were determined by flame photometric analysis. Leucocytes were counted in Celloscope 101, AB Lars Ljungberg and Co., Sweden. 
Text-figure 1 illustrates the typical variations in blood constituents during three successive copulations and control samplings recorded for Boar No. 1.

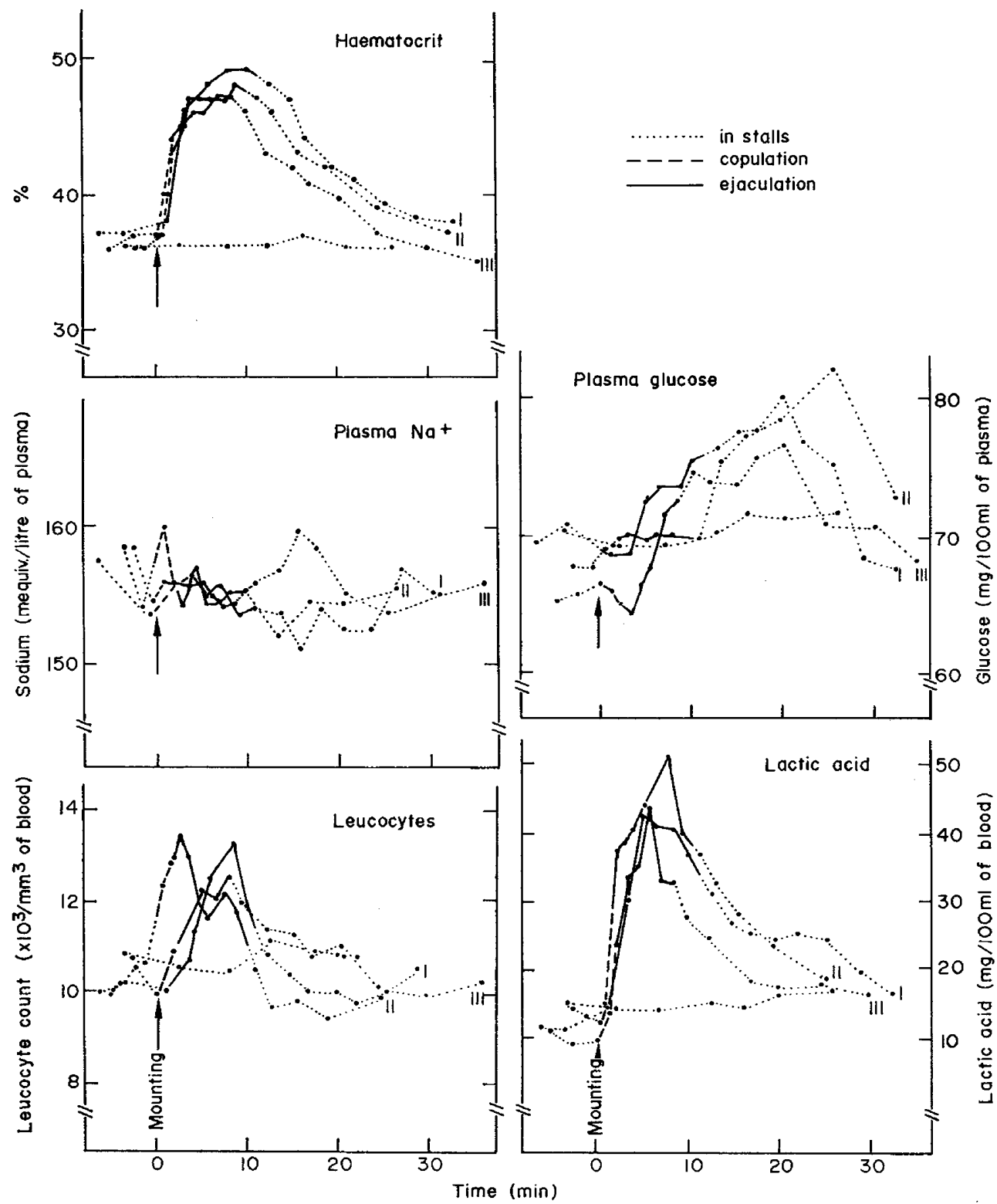

Text-Fig, 1. Haematocrit, plasma $\mathrm{Na}^{+}$, leucocytes, plasma glucose and lactic acid in boar's blood during copulation. Roman numbers denote successive copulations.

During the period of sexual excitement, at the commencement of copulation and during ejaculation, a rise in the haematocrit level was observed for each boar. Depending on the individual boar, these values rose, from 36 to $37 \%$ 
before copulation, to 44 to $49 \%$ during ejaculation and reached their highest levels during the passage of the bulbo-urethral gland secretions. Approximately 10 min after ejaculation, the haematocrit value reverted to the levels recorded before copulation. In general, the changes in the level of electrolytes in the blood resembled those for the haematocrit value, i.e. $\mathrm{K}^{+}$according to packed cell and $\mathrm{Na}^{+}$to plasma percentage, respectively. The content of $\mathrm{Na}^{+}$in plasma did not change during the period of sexual excitement and copulation in any of the boars examined. The observed increase in haematocrit and blood $\mathrm{K}^{+}$ accompanied by a decrease in blood $\mathrm{Na}^{+}$and lack of changes in plasma $\mathrm{Na}^{+}$ suggest a marked fall in plasma volume during ejaculation. It seems possible that the variation in the colour of blood observed during coitus (Fox \& Fox, $1969)$ and the greater values for erythrocytes, leucocytes and haemoglobin in boars just after ejaculation (Gudat \& Schnell, 1970) may be the result of changes in the plasma volume. Changes in the haematocrit and in the electrolytes of blood during copulation do not seem to be characteristic of this phenomenon only. Similar changes in the blood were also found during short-term periods ( 2 min) of physical stress in pigs (Kołczak \& Ewy, unpublished data).

Glucose concentration in the plasma usually rose from the moment of mounting the dummy or from the beginning of ejaculation. The plasma glucose rose throughout ejaculation and continued to rise for a further 7 to $13 \mathrm{~min}$, after which it dropped to the former level. Compared with the resting level, the content of glucose in plasma rose by 10 to $20 \mathrm{mg} / 100 \mathrm{ml}$ of plasma. Gudat \& Schnell (1970) found a higher level of glucose in the blood of boars just after ejaculation than before copulation. Kołczak, Wierzchoś, Rzeźnik \& Ewy (1970) demonstrated a similarity in the increase of glucose in the blood of boars after the emission of semen during copulation and after the intravenous injection of adrenaline. The level of plasma glucose depends on its supply to the blood, its transport from the blood to the tissues and the pool size distribution (plasma volume). When converting the concentration of glucose into a constant value of the haematocrit during copulation, the increase of plasma glucose during the initial phase of copulation clearly resulted from a fall in the pool size distribution and from transport of glucose from the blood since the increase of glucose was smaller than that of the haematocrit value. The absolute rise in the plasma glucose began during ejaculation or soon after passage of the sperm-rich fraction.

The level of lactic acid in the blood began to rise when the boar left the stall. During ejaculation, it was three to seven times higher than the resting level and the highest level was usually observed after passage of the sperm-rich fraction. The lactic acid content of the blood depends on the intensity of glycolytic processes in the tissues, especially in the muscles. This suggests a significant intensity of glycolytic processes associated with the activity of muscle during erection, copulatory movements and transport of the sperm-rich fraction in the male genital tract.

The number of leucocytes increased also during the period of sexual excitement and copulation and returned to the normal level after ejaculation.

With the exception of plasma glucose, the levels of the blood constituents examined had reverted to their resting values $20 \mathrm{~min}$ after ejaculation. From 
the physiological point of view, a period of 20 min sexual rest in the boar appears to be sufficient for the restoration of homeostasis.

\section{REFERENCES}

Barker, E. D. \& Summerson, W. H. (1941) The colorimetric determination of lactic acid in biological material. 7. biol. Chem. 138, 535.

Bergmeyer, H. U. \& Bernt, E. (1962) D-Glucose Bestimmung mit Glucose-Oxydase und Peroxydase. In: Methoden der enzymatischen Analyse, p. 123. Verlag Chemie GMBH, Weinheim.

Fox, C. A. \& Fox, B. (1969) Blood pressure and respiratory patterns during human coitus. 7. Reprod. Fert. 19, 405.

Gudat, E. \& Schnell, U. (1970) Zur Beeinflussung einiger Blutwerte von Besamungsebern durch der Deckakt. Fortpfl. Besam. Haustiere Bd. 6, 36.

JaKUBowski, H. S. (1966) Der Verlauf der Herzschlagfrequenz von Ebern während der Samengewinnung auf dem Phantom. Vet. Diss. F.U. Berlin.

Klumbies, G. \& Kleinsorge, H. (1950) Circulatory dangers and prophylaxis during orgasm. Int. 7. Sex. 4, 61 .

KolczaK, T., Wierchos, E., RzeźnIK, K. \& Ewy, Z. (1970) Zmiany w poziomie glukozy we krwi podczas kopulacji u knura. Acta physiol. pol. (in press).

Spincer, J., Rook, J. A. T. \& Towers, K. G. (1969) The uptake of plasma constituents by the mammary gland of the sow. Biochem. F. 111, 727.

Wrerzchoś, E. (1970) Przemieszczanie nasienia w drogach wyprowadzajacych u knura. Diss. Instytut Biologii Stosowanej, Kraków.

Wójcik, K. (1969) Mechanizm przesuwania sie plemników w meskich drogach płciowych. III. Kurczliwość nasieniowodów u tryka w czasie powstrzymywanej kopulacji. Zesz. Nauk. Wyzsz. Szk. roln. Kraków, Rozpr. 12. 